\title{
A Fast Pulse-Height Ratio Circuit
}

\author{
Eiichi Tanaka, Hardi Simadjaja* and Mikio Yamamoto \\ National Institute of Radiological Sciences, Anagawa, Chiba-shi, Japan, \\ * Bandung Atomic Reactor Center, \\ Djl. Kapitan Pattimura No. 71, Bandung, Indonesia \\ Received February 1, 1973
}

\begin{abstract}
A fast pulse-height ratio circuit suitable for position sensitive radiation detector is presented. The circuit is based on the linear to logarithmic conversion method using three semi-conductor diodes. By flowing constant standing current through these diodes in quiescent state, the circuit performance is, in principle, independent of temperature. The accuracy of the circuit is almost less than $\pm 1.5 \%$ of full scale for in put voltage range of $20-420 \mathrm{~m} V$ at a temperature between $O^{\circ} \mathrm{C}$ and $50^{\circ} \mathrm{C}$.
\end{abstract}

\section{Introduction}

Many of position sensitive radiation detectors produce two energy dependent position signals, $V_{A}$ and $V_{B}$, and the energy independent position information is obtained by taking the ratio, $V_{A} /\left(V_{A}+V_{B}\right)$. The denominator, $V_{A}+V_{B}$, is proportional to the energy deposited to the sensitive volume of the detector, and hence it is some times called "Energy signal".

With recent development of the position sensitive detectors, many authors have developed various pulse-height ratio circuits ${ }^{1)}$ (5). These include the use of special characteristics of diodes, transistors or field effect transistors (FET), the use of pulse-height to time conversion, and the use of linear to logarithmic conversion.

This paper describes a ratio circuit suitable to the use with a position sensitive proportional counters for $\beta$ - or X-rays, in which a large dynamic range in energy signal is required. The circuit principle is based on the linear to logarithmic conversion by using semiconductor diodes, and the design criteria are large dynamic range, fast response, small temperature dependency and variable sampling time.

\section{Circuit principle}

A blockdiagram of the whole system is shown in Fig. 1. Two input signals are amplified and summed to produce energy signal, $V_{A}+V_{B}$, which is proportional to the energy deposited to the sensitive volume of the detector. The energy signal is applied to a single channel pulse-height analyzer (dotted line) which consists of "Fast Pick Off", "Variable Delay", "Gate", "Lower Discriminator", "Upper Discriminator" and two "Uni-Vibrators".

The ratio circuit (broken line) is designed so as to produce a voltage output pulse proportional to $V_{A} /\left(V_{A}+V_{B}\right)$ at a variable sampling time determined by "Variable Delay" circuit if the energy signal passes the single channel pulse-height analyzer. The diodes $D_{1}$ and $D_{2}$ are linear to logarithmic conversion elements and the diode $D_{3}$ is a logarithmic to linear conversion element. These diodes are biased by constant currents, $I_{01}, I_{02}$, and $I_{03}$ respectively, in the quiescent state. When an energy signal exceeds the lower discriminator level, a negative rectangular pulse from "Uni-Vibrator" ( $3 \mu \mathrm{sec}$ ) cuts the bias currents, $I_{01}$ and $I_{02}$, off by the switching action of transistor $Q_{1}$ and $\mathrm{Q}_{4}$, and the signal currents, $I_{1}$ and $I_{2}$, flow through $D_{1}$ and $D_{2}$, respectively, by the action of the operational amplifiers " $\mathrm{A}_{1}$ " and " $\mathrm{A}_{2}$ ", where $I_{1}$ and $I_{2}$ are given by

$$
I_{1}=\left(2 V_{A}+V_{B}\right) / R \text { and } I_{2}=\left(V_{A}+V_{B}\right) / R
$$

If the currents, $I_{1}, I_{2}, I_{01}$ and $I_{02}$ are suff- 


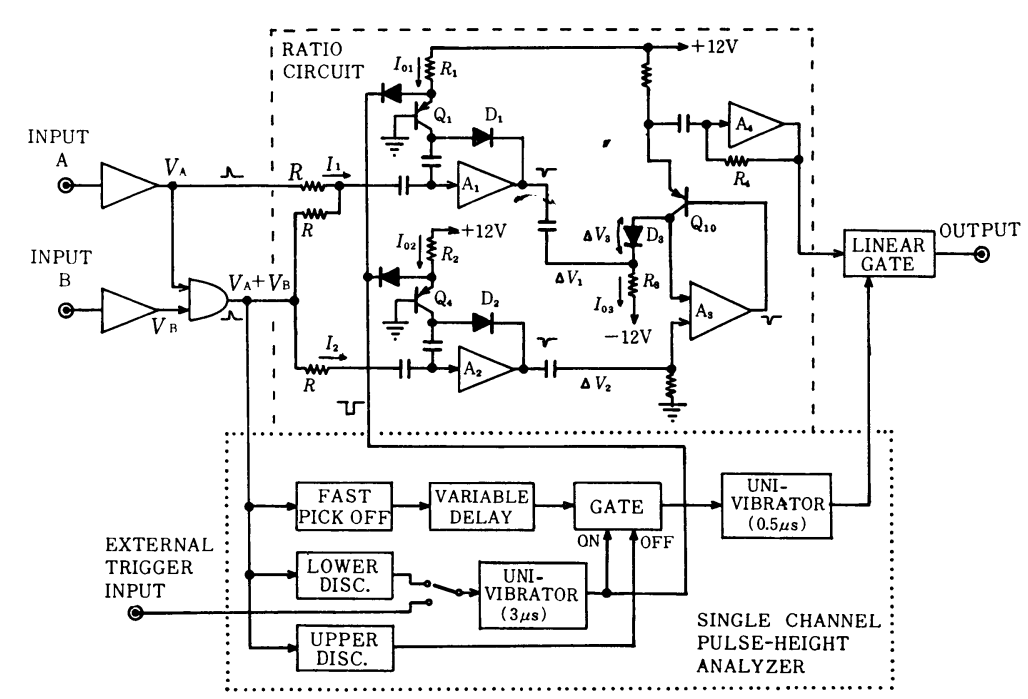

Fig. 1. Blockdiagram of the whole system showing the circuit principle.

ciently large as compared with the reverse saturation currents of the diodes, the output voltages of the two operational amplifiers, $A_{1}$ and $A_{2}$, can be expressed by

$$
\begin{aligned}
& \Delta V_{1}=(k T / q) \log \left(I_{1} / I_{01}\right) \\
& \Delta V_{2}=(k T / q) \log \left(I_{2} / I_{02}\right)
\end{aligned}
$$

respectively, where $q$ is the electronic charge, $T$ the temperature of the diodes in Kelvin, and $k$ the Boltzman constant.

At the same time, the differential operational amplifier " $\mathrm{A}_{3}$ " and transistor $\mathrm{Q}_{10}$ produces current, $I_{3}$ which flows through diode $\mathrm{D}_{3}$ so that the following relation holds:

$$
\Delta V_{3}=\Delta V_{1}-\Delta V_{2}
$$

where $\Delta V_{3}$ is the change in voltage across $D_{3}$. Since the diode $D_{3}$ is also biased by a constant current, $I_{03}$, there is a relation:

$$
\Delta V_{3}=(k T / q) \log \left\{\left(I_{3}+I_{03}\right) / I_{03}\right\}
$$

From eqs. $(2) \sim(5)$, we have

$$
I_{3}=\left(\frac{I_{02}}{I_{01}} \frac{I_{1}}{I_{2}}-1\right) I_{03}
$$

The change in current flowing through $D_{3}$ is then converted to a voltage output, $V_{\text {out }}$, by the operational amplifier " $\mathrm{A}_{4}$ ". The voltage output is given by, using eq.(1),

$$
V_{\text {out }}=R_{4} I_{3}=R_{4} I_{03}\left(\alpha \frac{V_{A}}{V_{A}+V_{B}}+\alpha-1\right)
$$

where $\alpha=I_{02} / I_{01}$. If the value of $\alpha$ is chosen to be larger than unity, $V_{\text {out }}$ is positive for any combination of $V_{A}$ and $V_{B}$.
The output voltage is then gated by a $0.5 \mu \mathrm{sec}$ ractangular pulse from the single channel pulse-height analyzer. The sampling time can be adjusted in the range from 0.5 to $3.0 \mu \mathrm{sec}$ by "Variable Delay" circuit.

It should be noticed that eq. (7) does not include any parameter sensitive to the temperature such as $(k T / q)$ or the reverse saturation current of the diodes, and hence the circuit will, in principle, show no temperature dependency as long as the three diodes are held at the same temperature. It is also essential that the three logarithmic elements are biased by a fairly large current in quiescent state to suppress excessive noise when there is no input signals.

The complete circuit of the ratio circuit are shown in Fig. 2. Epitaxial planner silicon transistors, $2 \mathrm{SC} 460$, in diode connection are used as the logarithmic elements, because they have better logarithmic characteristics than the conventional diodes ${ }^{6}$. The bias currents of the three logarithmic elements are determined by the resistance, $R_{1}, R_{2}$, and $R_{3}$, respectively. The switching transistors, $\mathrm{Q}_{1}$ and $\mathrm{Q}_{2}$, must have low $I_{\mathrm{CBO}}$ sufficiently smaller than input signals, $I_{1}$ and $I_{2}$. The selection of matched pair of the two logarithmic elements, $D_{1}$ and $D_{2}$, was important to obtain good performance. 


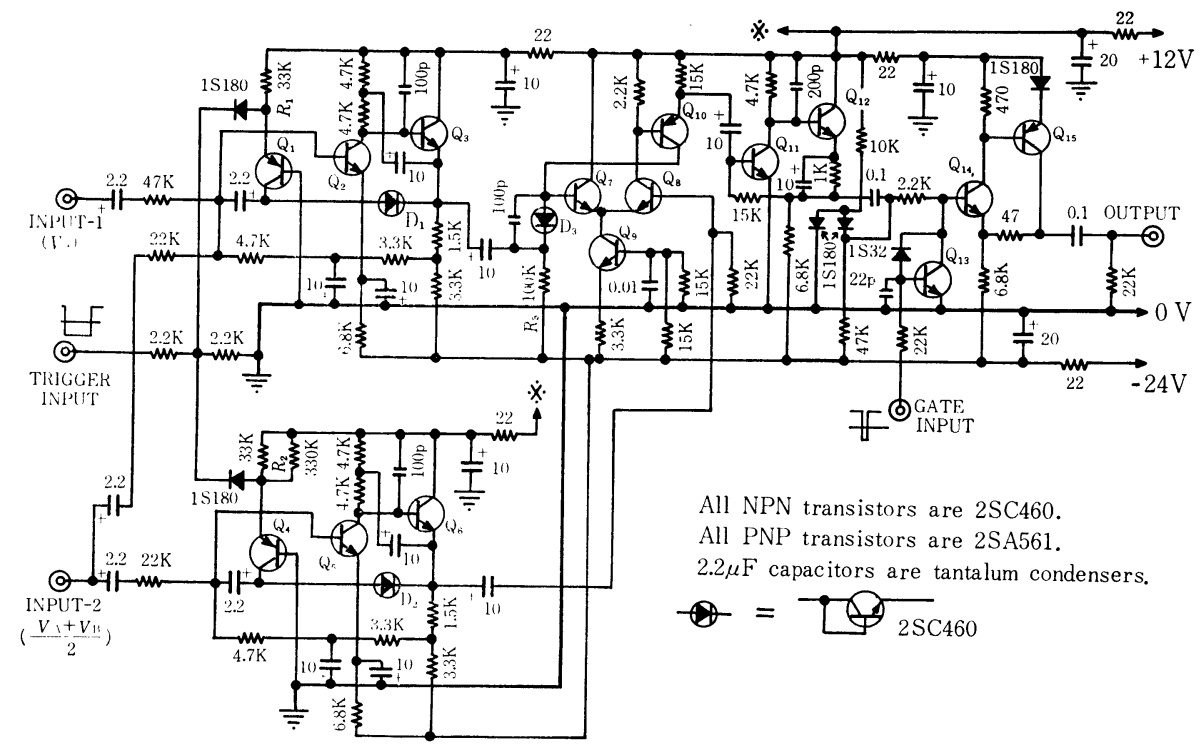

Fig. 2 Complete circuit diagram of the ratio circuit.

\section{Performance}

The performance test was made with a specially designed double pulse generator and a 200 channel pulse-height analyzer. The pulse generator is controled by a precise mercury pulser, and produces a pair of pulses having the same waveform as that of the mercury pulser. The ratio of their

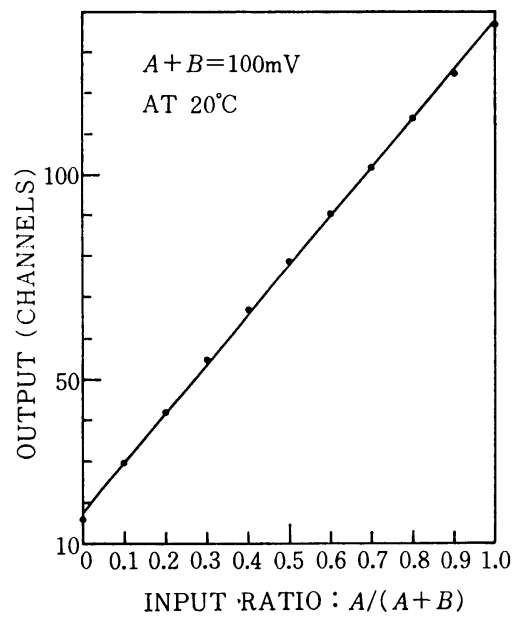

Fig. 3 Linearity of output vs. input pulseheight. $A$ and $B$ indicate the pulseheights of two input signals at the input terminals of the amplifiers. amplitudes can be changed in ten steps keeping the sum of them at a constant amplitude which is equal to that of the pulses from the mercury pulser.

The linearity, the dynamic range and the temperature dependency are shown in Figs. 3-5. $A$ and $B$ in the figures indicate the pulse-heights of signals at the input terminals of the amplifiers. The single channel pulse-height analyzer was set at the widest position, and the amplifier gain was set at about 10. The solid lines in these figures show the ideal characteristics. The deviation from the ideal is within $1.5 \%$ of the

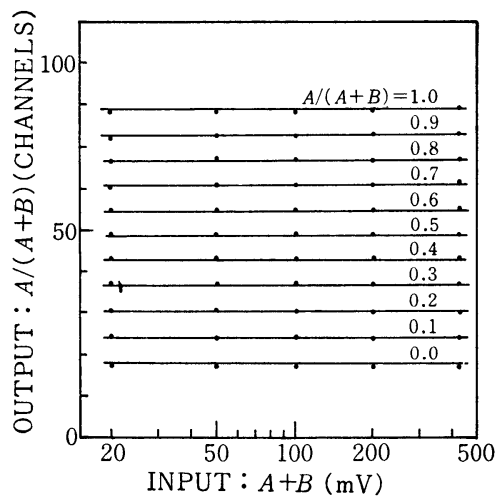

Fig. 4 Constancy of output for various input signals having constant ratio. 


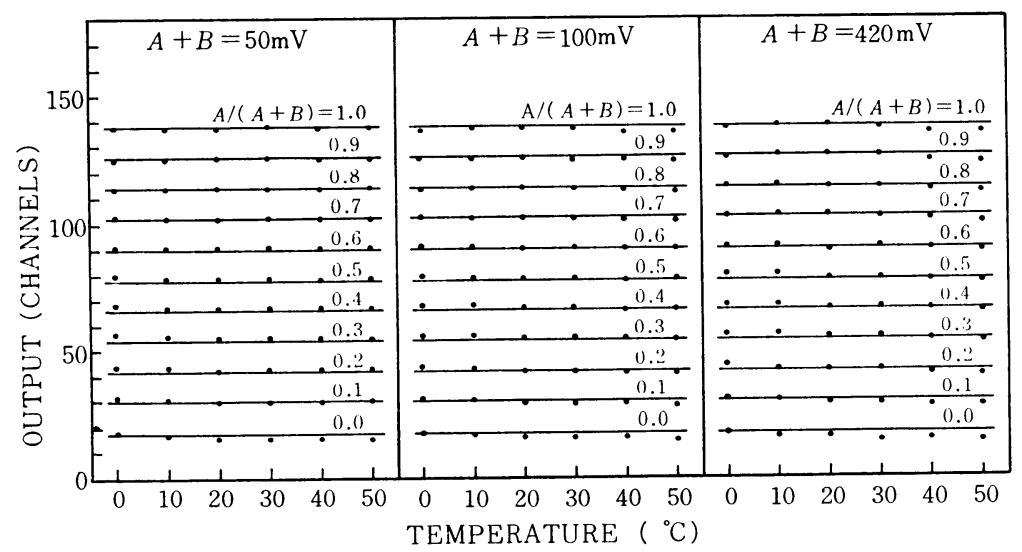

Fig. 5 Temperature dependence of the circuit for three input levels.

full scale for the input voltage range from 20 to $420 \mathrm{mV}$, and for $0^{\circ} \mathrm{C} \sim 50^{\circ} \mathrm{C}$, except for $20 \mathrm{mV}$ at $0^{\circ} \mathrm{C}$.

The rise time of the output from the operational amplifier " $\mathbf{A}_{4}$ " is a function of the input voltage, and it ranges from about $0.5 \mu \mathrm{sec}$ for the smallest pulse to $0.1 \mu \mathrm{sec}$ for the largest pulse in the usable dynamic range. The high count rate performance was tested with random pulses from a scintillation detector. The pulse-height of output of the system was decreased by $1.5 \%, 2 \%$, $3 \%$, and $4 \%$ at $15,20,35$, and $60 \mathrm{kcps}$, respectively.

\section{References}

1) G.L. Miller and E.A. Gere: IEEE Trans., NS-11, (3) 382 (1964)

2) W.R. Kuhlmann and B. Scimmer: Nucl. Instr. Meth., 40, 113 (1966)

3) A. Doehring, S. Kalbitzer, W. Melzer and W. Stumpfi: Nucl. Instr. Meth., 40, 42 (1969)

4) D.J. Herrell: J. Sci. Instr., Series 2, 1, 1217 (1968)

5) S. Nakamoto: Radioisotopes (Tokyo), 20, 21 (1971)

6) G.E. Platzer: Electronics, 39, (7) April 4, 109 (1966)

\title{
要 旨
}

\author{
高速パルス比回路 \\ 田中栄一，ハーディ・シマジャヤ*，山本幹男 \\ 放射線医学総合研究所, 千葉市穴川 4 丁目, \\ * バンドン原子力センター，インドネシヤ・バンドン市
}

\footnotetext{
放射線位置検出器に適する高速パルス比回路について報告する。この回路は 3 個の半導体ダイオ ードを使用した「直線——対数」変換法に基つくものである。パルス信号のない期間中 3 個のダイ オードに一定の直流電流を流しておくことにより, この回路の動作恃温度変化の影響を原理的に受 けない。この回路の精度は, 温度 $0^{\circ} \mathrm{C} \sim 50^{\circ} \mathrm{C}$ 範囲で $20 \mathrm{mV} \sim 420 \mathrm{mV}$ の入力信号にたいし，フル スケールのはほ $\pm 1.5 \%$ 以内である。
} 